\title{
HYDROCYANIC ACID CONTENT AND GROWTH RATE OF SORGHUM X SUDANGRASS HYBRID DURING FALL
}

\author{
Teor de ácido cianídrico e taxa de crescimento do híbrido de \\ sorgo $x$ capim sudão durante o outono
}

\author{
Flávia Fernanda Simili', Maria Lúcia Pereira Lima², Maria Izabel Merino de Medeiros³, \\ Claudia Cristina Paro de $\mathrm{Paz}^{2}$, Ana Claudia Ruggieri', Ricardo Andrade Reis ${ }^{4}$
}

\begin{abstract}
In central Brazil after soybean or other annual agricultural species is harvested, sorghum hybrids are planted in the fall in order to establish pastures for grazing animals. This study conducted for two consecutive years aimed at quantifying the contents of hydrocyanic acid in the leaves and determining plant height, forage dry matter yield and the leaf/stem ratio for sorghum hybrid $1 \mathrm{P} 400$ at different ages. Statistical analysis was performed by regression analysis based on plant age. Leaf HCN content decreased with plant growth, ranging from 205.0 and $230.3 \mathrm{mg} \mathrm{HCN} / 100 \mathrm{~g}$ leaf DM at two weeks old to 5.9 and $6.1 \mathrm{mg} \mathrm{HCN} / 100 \mathrm{~g}$ leaf DM at five weeks old in the first and second year, respectively. The average heights measured varied from 60 and $56 \mathrm{~cm}$, in the $4^{\text {th }}$ week, to 117 and $151 \mathrm{~cm}$, in the $8^{\text {th }}$ week, during the first and second experimental year, respectively. Forage mass increased linearly with age and displayed average of 1.411 and $1.637 \mathrm{~kg} \mathrm{DM} / \mathrm{ha}$ in the first year and, 2.905 and $3.640 \mathrm{~kg} \mathrm{DM} / \mathrm{ha}$ in the second year, during the $7^{\text {th }}$ and $8^{\text {th }}$ week, respectively. Leaf proportion decreased while stem increased linearly with plant age. The leaf/stem ratio decreased with plant growth, elongation and increasing stem weight. The sorghum hybrid should be grazed only after five weeks or when the plant height is above $80 \mathrm{~cm}$, in order to avoid the risk of cyanide poisoning.
\end{abstract}

Index terms: Annual grasses, cyanogenic plants, picro-sodium test, toxic plant.

\section{RESUMO}

No Brasil Central, híbridos de sorgo podem ser semeados no outono, após a colheita da soja ou outra espécie de planta anual, com o objetivo de fornecer alimento aos ruminantes por meio de pastejo. O trabalho foi desenvolvido, por dois anos consecutivos, com o objetivo de quantificar os teores de ácido cianídrico das folhas e mensurar a altura das plantas, produção de massa seca de forragem e a proporção de folha e colmo nas diferentes idades do hibrido de sorgo IP400. A análise estatística foi realizada por meio de análise de regressão em função da idade das plantas. O teor de HCN nas folhas decresceu com o desenvolvimento das plantas, apresentando 205,0 e 230,3 mg HCN/100 g de MS de folha, com duas semanas de crescimento e 5,9 e 6,1 mg HCN/100 g de MS de folha, na quinta semana de crescimento, no primeiro e segundo ano, respectivamente. As plantas apresentaram em média 60 e $56 \mathrm{~cm}$, na $4^{\mathrm{a}}$ semana, e 117 e $151 \mathrm{~cm} \mathrm{na} 8^{\mathrm{a}}$ semana, no primeiro e segundo ano, respectivamente. A massa de forragem aumentou linearmente, com a idade, apresentando, em média, na sétima e oitava semanas de avaliação, 1.411 e $1.637 \mathrm{~kg}$ de MS/ha no primeiro ano e 2.905 e $3.640 \mathrm{~kg}$ de MS/ha no segundo ano, respectivamente. Com o crescimento das plantas, a proporção de folhas diminuiu e a proporção de colmo aumentou linearmente. A relação folha/colmo diminuiu com o crescimento, com o alongamento das plantas e aumento do peso dos colmos. O híbrido de sorgo deve ser pastejado, somente após a quinta semana de crescimento ou quando as plantas tiverem acima de $80 \mathrm{~cm}$ para não haver risco de intoxicação por HCN.

Termos para indexação: Gramíneas anuais, planta cianogênica, teste picro-sódico, planta tóxica.

\section{(Received in may 28, 2013 and approved in july 5, 2013)}

\section{INTRODUCTION}

In tropical regions, such as central Brazil, sorghum hybrids can be planted off-season in February or March (fall), after soybean or other annual species is harvested, in order to provide feed to grazing ruminants. On the other hand, young sorghum plants are considered cyanogenic because they contain cyanogenic glycoside, esters that can release toxic substances when the plant structure breaks due to stress caused by grazing, trampling or drought (GILLINGHAM, 1969; MELO, 2003; MONTAGNER, 2005).

${ }^{1}$ Agência Paulista de Tecnologia dos Agronogócios/APTA - Secretaria de Agricultura e Abastecimento/SAA - Avenida Bandeirantes - Ribeirão Preto 14.030-670 - São Paulo - SP - Brasil - flaviasimili@gmail.com

${ }^{2}$ Agência Paulista de Tecnologia dos Agronogócios/APTA - Secretaria de Agricultura e Abastecimento/SAA - Ribeirão Preto - São Paulo - SP - Brasil ${ }^{3}$ Instituto de tecnologia de Alimentos/ITAL - Agência Paulista de Tecnologia dos Agronogócios/APTA - Secretaria de Agricultura e Abastecimento/SAACampinas - SP - Brasil

${ }^{4}$ Universidade Estadual Paulista "Julio de Mesquita Filho"/UNESP - Faculdade de Ciências Agrárias e Veterinárias - Campus de Jaboticabal Jaboticabal - SP - Brasil 
Dhurrin, the most important cyanogenic glucoside, in the presence of the enzyme b-glucosidase releases sugar and hydrocyanic acid (HCN), a colourless very volatile liquid, considered one of the most toxic substances ever known. Ruminants are more susceptible to $\mathrm{HCN}$ intoxication compared to monogastric. The acidic stomach $\mathrm{pH}$ of monogastrics do not allow the enzyme linamarase to act and, therefore, the cyanide release slows down, allowing time for its elimination without reaching the lethal dose (DOWLING; MACKENZIE, 1993). However, in ruminants the combination of neutral $\mathrm{pH}$ and the presence of bacteria capable of hydrolysing linamarina are considered high risk since cyanide is released rapidly and may reach the lethal dose before being eliminated from the animal organism. Haque et al. (2002) also studied pH effect and concluded that $\mathrm{HCN}$ is more toxic in neutral $\mathrm{pH}$.

Nóbrega Junior. et al. (2006) investigated HCN poisoning in goats feeding on Sorghum halepense (L.) Pers., a highly toxic and invasive species. The goats, after 30 days, showed severe dyspnoea and frequent urination, sign of acute poisoning that lead to death.

Several sorghum varieties and hybrids with different $\mathrm{HCN}$ potential in their leaves have been studied, and a strong genetic effect/component was detected on the HCN content in the plants (LAMB et al., 1991). Wheeler et al. (1990) studied the hybrids S. bicolor (L.) Moench and $S$. sudanense (Piper) Stapf and reported strong influence of nitrogen fertilization and plant age on the $\mathrm{HCN}$ contents in the leaves. The regrowth forage of Zulu hybrid, after three weeks, had $100 \mathrm{mg} \mathrm{HCN} / 100 \mathrm{~g}$ DM when fertilized with $200 \mathrm{~kg} \mathrm{~N} / \mathrm{ha}$ and $76 \mathrm{mg} \mathrm{HCN} / 100 \mathrm{~g} \mathrm{DM}$ without topdressing while the hybrid Silk had $185 \mathrm{mg} \mathrm{HCN} / 100 \mathrm{~g}$ DM when fertilized with $200 \mathrm{~kg} \mathrm{~N} / \mathrm{ha}$ and $33 \mathrm{mg} \mathrm{HCN} / 100$ g DM without topdressing, thus showing different behaviour for different hybrids. Fertilization with phosphate did not affect HCN levels while concentrations of HCN dropped sharply with age, plant height and number of expanded leaves.

An important factor for the accumulation of $\mathrm{HCN}$ is the rapid plant regrowth after the first rains, which can be compounded by a period of rapid growth after slow growth periods due to drought or low temperatures (GORASHI; DROLSOM; SCHOLL, 1980; RADOSTITS, 2002).

Even for different regions and assessment times, the sorghum hybrid shows flexibility regarding planting season and good forage yield. Simili et al. (2010) studied irrigated sorghum AG 2501C and reported 4 grazing cycles with an average yield of $2.800 \mathrm{~kg} \mathrm{DM} / \mathrm{h}$ a per cut, from April toSeptember, 2002. Another study with two sowings (December and March) had similar yields for the sorghum hybrid 1P400, 3.234 and $3.135 \mathrm{~kg}$ DM/ha per cutting, respectively (SIMILIet al., 2011).

It is necessary to establish whether the sorghum hybrid 1P400 poses the risk of cyanide poisoning for grazing cattle and the ideal plant age when grazing provides good forage for the animals and the risk of poisoning is not present any longer. Studies of this nature are of great importance for cattle, sheep and goats due to the increasing use of this grass for grazing in various tropical regions.

The aim of this study was to quantify the levels of hydrocyanic acid in the leaves, to determine plant height, forage dry matter yield and the leaf/stem ratio at different harvesting dates of hybrid sorghum IP400 to establish the ideal time to start grazing by cattle.

\section{MATERIAL AND METHODS}

The experiment was conducted for two consecutive years at the experimental farm of the Agência Paulista de Tecnologia dos Agronegócios (APTA) in Ribeirão Preto, mid-east region of Sao Paulo state (21 ${ }^{\circ} 42^{\prime}$ S , $47^{\circ} 24^{\prime} \mathrm{W}$ and altitude $535 \mathrm{~m}$ ). The climate is tropical with dry winter. High and low temperatures, as well as rainfall in the region, are shown in figure 1 .
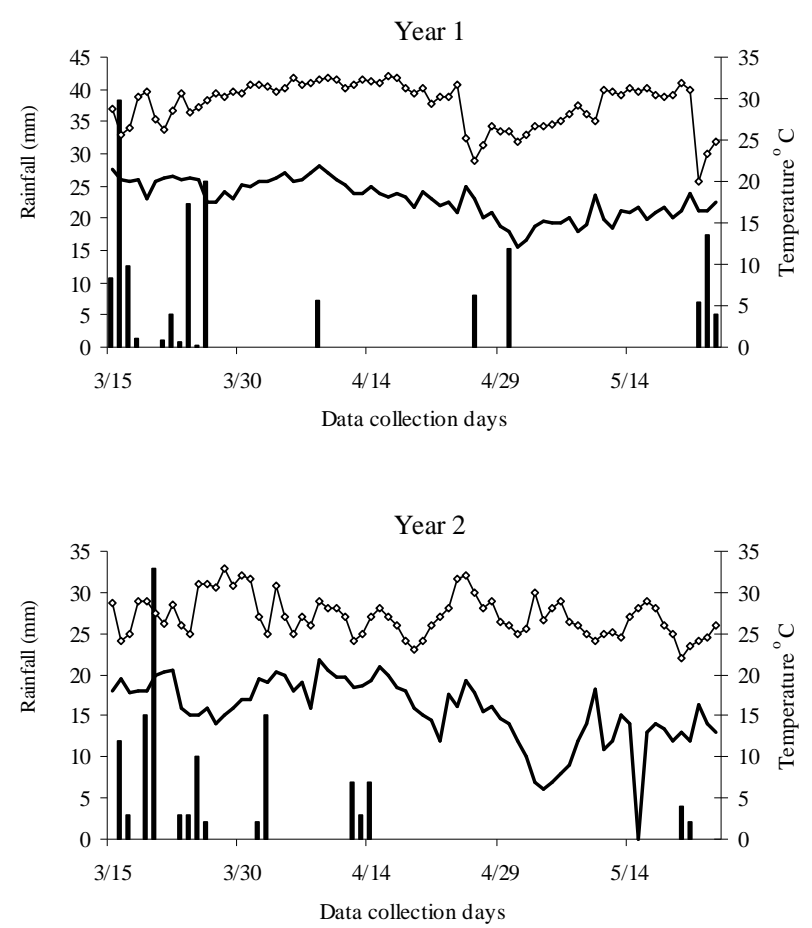

Figure 1 - Rainfall and maximum and minimum temperatures during the two experimental years in Ribeirão Preto, São Paulo, Brazil. 
The area has a slightly undulating relief and the soil is classified as Dystroferric Red Latosol (EMPRESA BRASILEIRA DE PESQUISA AGROPECUÁRIAEMBRAPA, 1999). The sorghum was planted in a $600 \mathrm{~m}^{2}$ area divided into three plots of $200 \mathrm{~m}^{2}(4 \times 50)$ each, with two repetitions per plot. The chemical characteristics of soil samples collected from every plot were: plot $1, \mathrm{pH}$ $\mathrm{CaCl}_{2}=4.9$; organic matter $=43 \mathrm{~g} / \mathrm{dm}^{3} ;$ phosphorus in resin $=38 \mathrm{mg} / \mathrm{dm}^{3}$; sum of bases $=48.9 \mathrm{mmol} / \mathrm{dm}^{3}$; and base saturation, $\mathrm{V} \%=51 \%$. Soil samples from plot 2 displayed $\mathrm{CaCl}_{2}=4.6$; organic matter $=37 \mathrm{~g} / \mathrm{dm}^{3} ;$ phosphorus in resin $=30 \mathrm{mg} / \mathrm{dm}^{3} ;$ sum of bases $=42.1 \mathrm{mmol} / \mathrm{dm}^{3} ;$ and $\mathrm{V} \%=$ $42 \%$ while for plot $3, \mathrm{pHCaCl}_{2}=4.9$; organic matter $=40 \mathrm{~g} /$ $\mathrm{dm}^{3} ;$ phosphorus in resin $=21 \mathrm{mg} / \mathrm{dm}^{3} ;$ sum of basis $=45.4$ $\mathrm{mmol} / \mathrm{dm}^{3} ;$ and $\mathrm{V} \%=49 \%$.

The weeds were desiccated using glyphosate herbicide before sowing. Sowing was performed on March 20 in both experimental years, under the no-tillage system, using $12 \mathrm{~kg}$ seed/ha of the sorghum hybrid (S. bicolor $\mathrm{x} S$. sudanense) 1P400, by Dow Agrosciences, recommended for grazing. Fertilization used $120 \mathrm{~kg} / \mathrm{ha}$ of $8-28-16+\mathrm{Zn}$ fertilizer, without topdressing since there was residual fertilization of the soybean culture planted earlier in both experimental years.

Plant sampling was random within each plot and consisted of cutting a meter of grass at ground level for each repetition, two per plot. The samples were then taken to the laboratory where they were weighed and separated according to each response variable. The response variables studied were: hydrocyanic acid content of the leaves, forage dry matter yield (FDM), plant height, proportion of leaves and stems and leaf/stem ratio (L/S).

The first samples were collected at the end of the second growth week, so the plants were 14 days old and continued until the inflorescences emerged in the eighth week.

The hydrocyanic acid content was measured in the leaves until values were close to zero, that is, until the $5^{\text {th }}$ week for both experimental years. The HCN content was determined by the Guignard test (MONTGOMERY, 1969), which is a semi-analytical quantifying testing where the resulting colours are compared to a standard. Sodium picrate paper is prepared by dipping the filter paper $( \pm 1 \mathrm{x}$ $10 \mathrm{~cm}$ ) into a picric acid and sodium carbonate solution. The 1P400 sorghum hybrid leaves were separated into leaf blades and stems (with sheath), chopped and weighed into \pm 0.5 -g samples that were then placed into lidded test tubes $(2 \times 12 \mathrm{~cm})$ and added water $( \pm 1 \mathrm{~mL})$. The sodium picrate filter papers were suspended into the test tubes from the lid, which were taken to a water bath at $38^{\circ} \mathrm{C}$, for at least $12 \mathrm{~h}$. The result was considered positive when the colour of the sodium picrate paper strip changed from yellow to earthy red. Subsequently, the sorghum hybrid 1P400 paper strips were compared to a standard curve prepared for a potassium cyanide solution containing 0 to $1 \mathrm{mg}$ cyanide per $\mathrm{mL}$. The amount of hydrocyanic acid was then determined over time (in weeks) by calculating the $\mathrm{HCN}$ per gram of leaf drymatter.

Forage dry matter was obtained from the subsample containing the plant tops that were dried in a forced air drying oven at $55^{\circ} \mathrm{C}$, for at least 72 hours until constant weight (SILVA; QUEIROZ, 2002).

Plant height was determined in ten sampling points per meter using a $\mathrm{cm}$-graduated ruler placed at the leaf inflection point or the tip of the flag leaf, when there was inflorescence.

The different forage fractions were obtained from the subsamples that were separated into leaf (leaf blade) and stem (with sheath). These fractions were also dried in a forced air drying oven at $55^{\circ} \mathrm{C}$, for at least $72 \mathrm{~h}$ until constant weight to determine dry matter content. The leaf/ stem ratio was obtained by dividing leaf dry matter and stem plus sheath dry matter.

Statistical analysis was performed by regression analysis based on plant age, using the software PROC GLM (STATISTICALANALYSIS SYSTEM - SAS, 2003) for each experimental year separately.

\section{RESULTS AND DISCUSSION}

During the first experimental year, leaf HCN content decreased with aging plants (Figure 2). The values ranged from 205 to $5.9 \mathrm{mg} \mathrm{HCN} / 100 \mathrm{~g}$ leaf dry matter for two- and 5-week old plants, respectively. In the second year, the hydrocyanic acid curve behaved differently (Figure 2) since HCN content increased until the fourth week, with average $230.3 \mathrm{mg} \mathrm{HCN} / 100 \mathrm{~g}$ leaf $\mathrm{DM}$, and decreased rapidly until the fifth week, when the plants reached average $6.1 \mathrm{mg} \mathrm{HCN} / 100 \mathrm{~g}$ leaf DM (Figure 2).

Haque et al. (2002), also studied HCN content of sorghum leaves (S. vulgare Pers.) in Australia and reported at the end of the $2^{\text {nd }}, 3^{\text {rd }}$ and $4^{\text {th }}$ growth weeks the following toxic levels of HCN: 280, 40 and $60 \mathrm{ppm} \mathrm{HCN} \mathrm{in}$ fresh leaves and, therefore, they recommended that the livestock producers should monitor carefully the grazing activity.

Levels between 75 and $100 \mathrm{mg} \mathrm{HCN}$ per 100 grams of leaf dry matter poses a poisoning danger, when the leaves are ingested by ruminants according to Wall and Ross (1975). The greater values found in the present study 
point out towards potential poisoning risk in case the sorghum hybrid IP400 is consumed by the cattle during this period.
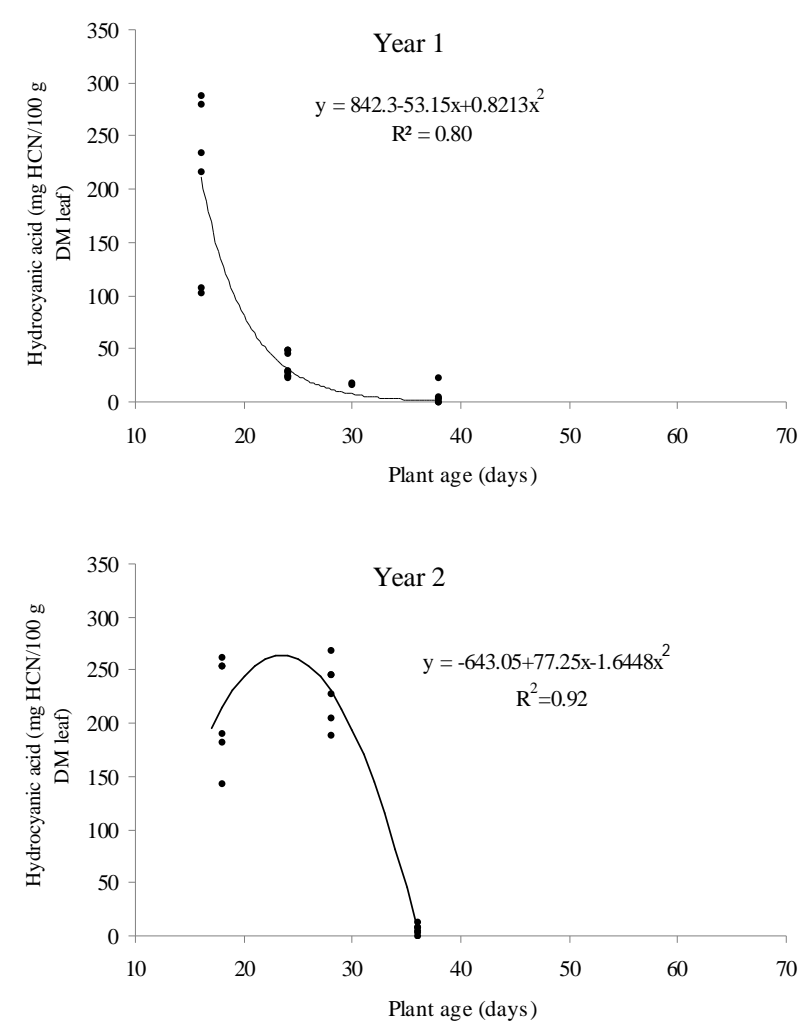

Figure 2 - Hydrocyanic content (mg HCN/100g leaf dry matter) of the hybrid Sorghum bicolor x Sorghum sudanense 1P400 assessed in two experimental years in Ribeirão Preto, São Paulo, Brazil.

A greenhouse experiment, where the plants were cultivated under controlled temperature at $30^{\circ} \mathrm{C}$ and $20^{\circ} \mathrm{C}$ during the day and night, respectively, and another where the temperatures were changed to $20^{\circ} \mathrm{C}$ and $10^{\circ} \mathrm{C}$ during the day and night, respectively showed that $\mathrm{HCN}$ contents were higher in younger leaves and increased significantly at lower temperatures (GORASHI et al., 1980). This study corroborates this trend towards lower temperatures. During the second experimental year, when the temperatures were lower, the poisoning risk was present until the $5^{\text {th }}$ week ( 35 day old plants) when plant height was $80 \mathrm{~cm}$. During the growth period between 14 and 28 days (from April 3 to 17), in the second year, the temperatures fluctuated between 16 and $20^{\circ} \mathrm{C}$ (Figure 1) while in the first year, at the same time, the temperatures fluctuated between 20 and $32^{\circ} \mathrm{C}$ (Figure 1). In the latter, when the grass was only $48 \mathrm{~cm}$ tall at 21 days old there was no poisoning risk and the grass was safe to grazing as early as the $3^{\text {rd }}$ week. Mulcahy et al. (1992) investigated some sorghum varieties for grazing and also reported large difference for $\mathrm{HCN}$ levels depending on the period, in the first year, the average was $570 \mathrm{mg} / \mathrm{kg} \mathrm{DM}$ while in the second year, the average was $123 \mathrm{mg} / \mathrm{kg}$ DM.

Figure 3 shows plant height versus time (age). For both experimental years, plant height was close to $50 \mathrm{~cm}$ at the end of the $4^{\text {th }}$ week $(60 \mathrm{~cm}$ and $56 \mathrm{~cm}$ average in the first and second year, respectively). During the second year, the grass displayed fast growth from the $5^{\text {th }}$ week until the end of the evaluation period and final height was bigger than in the first year. The sorghum hybrid $1 \mathrm{P} 400$ reached heights of 117 and $151 \mathrm{~cm}$ at the end of the $8^{\text {th }}$ week, in the first and second year, respectively.
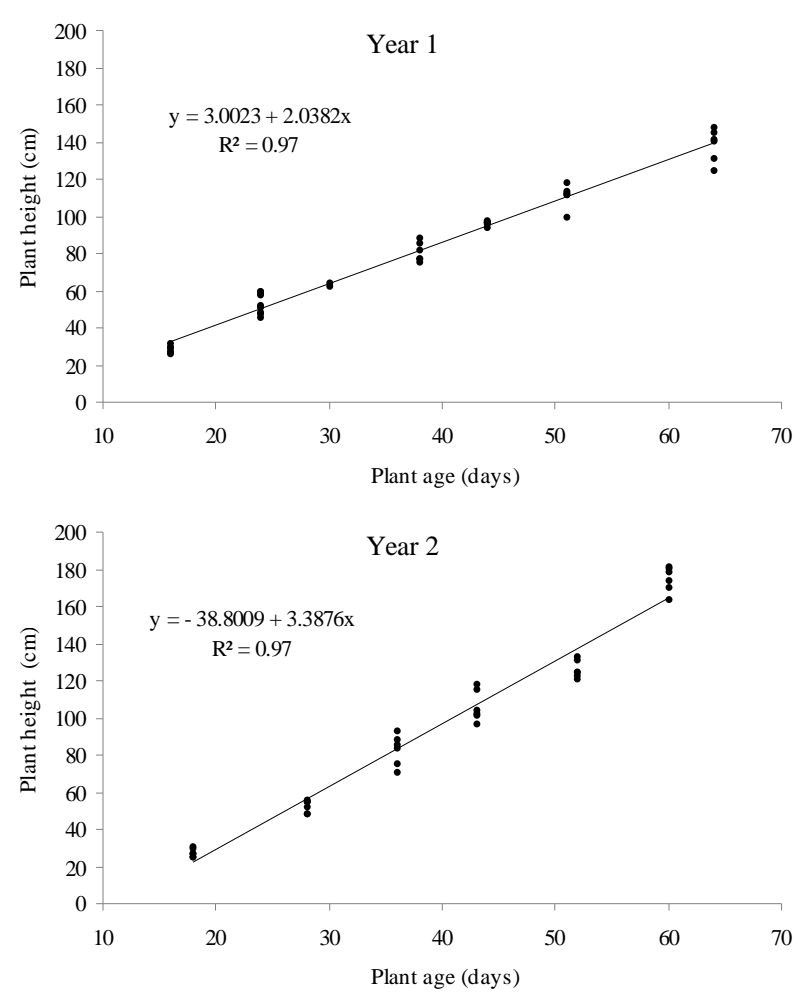

Figure 3 - Plant height of the hybrid Sorghum bicolor $x$ Sorghum sudanense 1P400 determined for two experimental years in Ribeirão Preto, São Paulo, Brazil.

Melo et al. (2003) while investigating the sorghum hybrid AG2501C reported a height of $105 \mathrm{~cm}$ for a 50 -

Ciênc. agrotec., Lavras, v. 37, n. 4, p. 299 - 305, jul./ago., 2013 
day old plant, which was sowed in November in a crop area in Rio Grande do Sul, similar to the result reported in this study.

Herbage mass increased linearly with sampling time for both years (Figure 4); furthermore, in the second year, the higher rainfall recorded at the beginning of the year (Figure 1) resulted in even higher herbage mass. The rainfall accumulated during the first 30 days of culture was 62.1 and $100 \mathrm{~mm}$ in the first and second year, respectively.
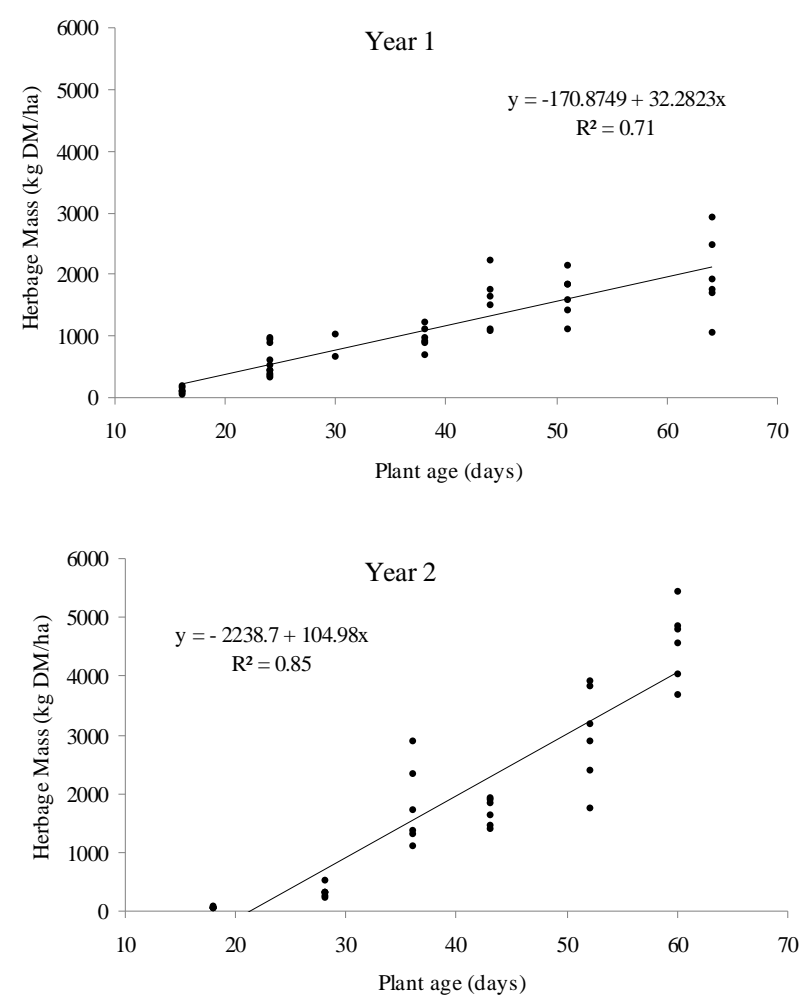

Figure 4 - Herbage dry matter of the hybrid Sorghum bicolor x Sorghum sudanense 1P400 assessed in two experimental years in Ribeirão Preto, São Paulo, Brazil.

$\mathrm{DM} / \mathrm{ha}$ in the first year and, 2905 and $3640 \mathrm{~kg} \mathrm{DM} /$ ha in the second year, respectively, showing that rainfall strongly influenced plant growth rate during the fall.

Montagner et al. (2005) studied eight varieties of sorghum hybrid cultivated in Rio Grande do Sul, from December to January and reported dry matter yield between 700 and $1580 \mathrm{~kg} / \mathrm{ha}$, for 35 and 40-day old sorghum, similar to the values found in this study for 2005.

Mello et al. (2003) studied the sorghum hybrid AG2501C and reported an yield of $1770 \mathrm{~kg} \mathrm{DM} / \mathrm{ha}$ after
50 days of growth, similar to the value found in the first year of this study, on the other hand, Simili et al. (2011) found for the sorghum hybrid 1P400, dry matter yields of 3234 and $3135 \mathrm{~kg} / \mathrm{ha}$ per cutting for an irrigated crop, values closer to the results of the second year of this study.

Figures 5 and 6 show the fractions of leaves and stem. The leaf fraction decreased with the growth rate (Figure 5) while the ratio stem/sheath increased linearly (Figure 6). The hybrid sorghum grass displays cespitose growth habit with a great ability to grow stems, which despite being nutritious, are not efficiently consumed when their height exceeds $1.20 \mathrm{~m}$ in grazing systems.
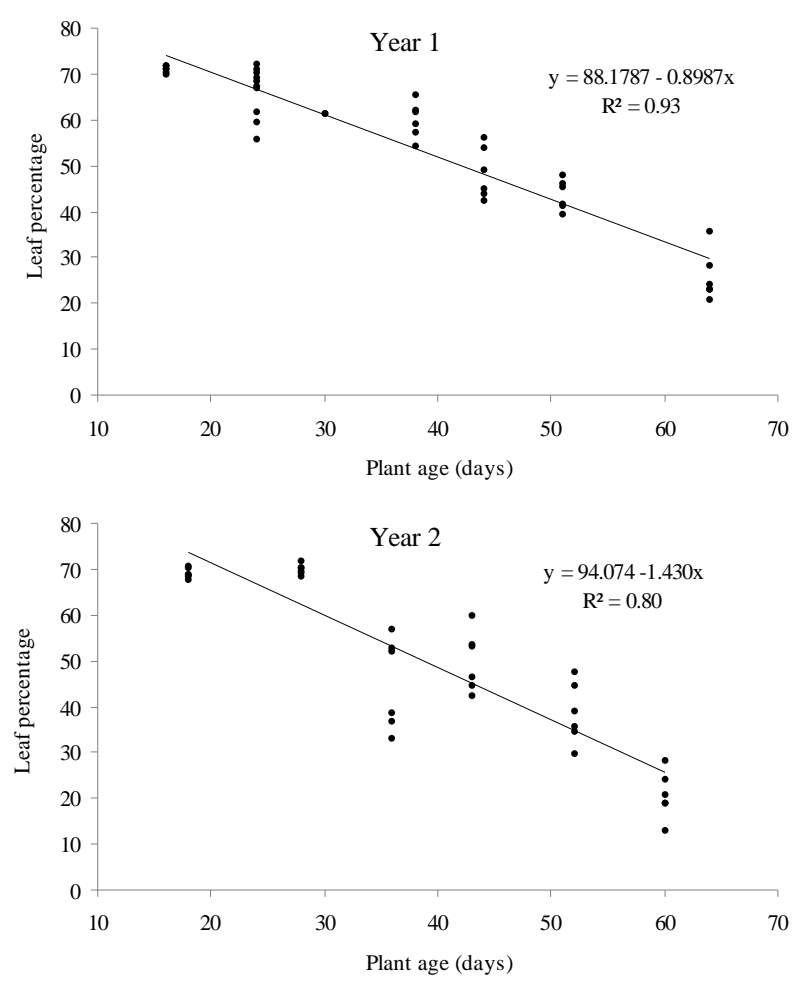

Figure 5 - Percentage of dry leaves of the hybrid Sorghum bicolor x Sorghum sudanense 1P400 assessed in two experimental years in Ribeirão Preto, São Paulo, Brazil.

The plants reached the height of $90 \mathrm{~cm}$ in the sixth and fifth week in the first and second year, respectively, which represented $50 \%$ leaf fraction.

Melo et al. (2003) reported $52.5 \%$ of leaves after 50 days for the sorghum hybrid AG 2501C, in Rio Grande do $\mathrm{Sul}$, when the plant height was $105 \mathrm{~cm}$, different from the values found in this study. 

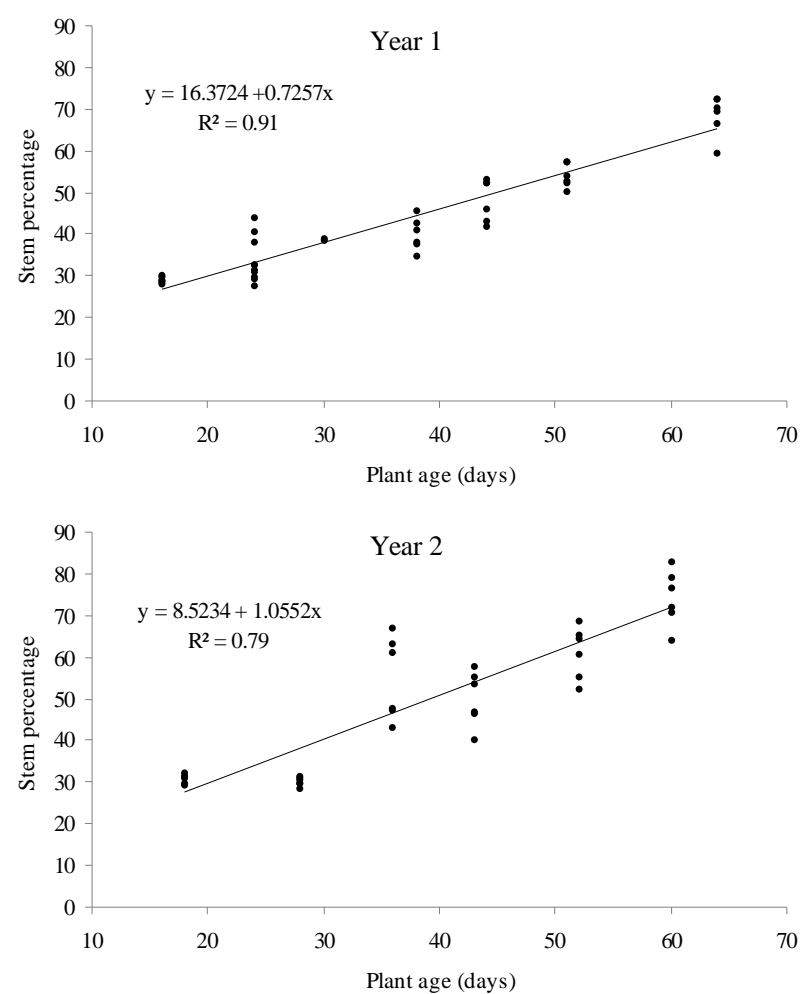

Figure 6- Percentage of dry stem (with sheath) of the hybrid Sorghum bicolor $\mathrm{x}$ Sorghum sudanense 1P400 assessed in two experimental years in Ribeirão Preto, São Paulo, Brazil

The leaf/stem ratio decreased significantly from the fifth week of growth (Figure 7) due to elongation and consequent weight increase, as it is characteristic of sorghum plants. Mulcahy et al. (1992) studied some varieties of sorghum as a herbage and reported a leaf/stem ratio ranging from 1.11 to 1.50 for plant heights between 90 and $95 \mathrm{~cm}$, respectively, higher and better values compared to this study.

The leaf/stem ratio is an important characteristic of canopy structure mainly regarding tropical grasses that present rapid stem development (STOBBS, 1973; SILVA; GOMIDE, 1994). This characteristic can influence animal grazing behaviour (STOBBS, 1973) and their performance as well (SILVA; GOMIDE, 1994; EUCLIDES, 1999). Accordingly, Stobbs (1973) showed that longer grazing intervals are associated with higher total biomass density but generally lower leaf density. Thus, stem elongation despite intensifying herbage accumulation, compromises canopy structure decreasing the leaf/stem ratio and sorghum intake by the animals.

In this context, the sorghum hybrid should be grazed when height is between 90 and $100 \mathrm{~cm}$, the leaf/ stem ratio varies between 1.5 and 0.8 and there is no poisoning risk by $\mathrm{HCN}$. However, the time necessary to reach this height depends on the amount of water available in the soil for plant growth.
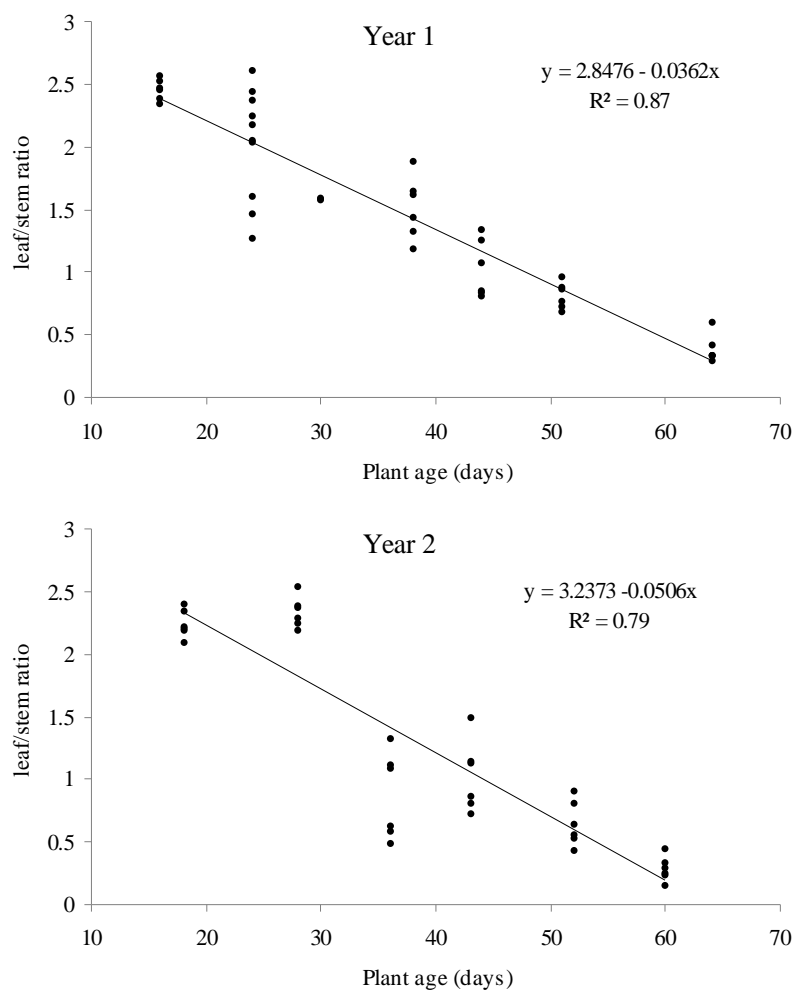

Figure 7 - Leaf/stem ratio of the hybrid Sorghum bicolor $\mathrm{x}$ Sorghum sudanense 1P400 assessed in two experimental years in Ribeirão Preto, São Paulo, Brazil.

\section{CONCLUSIONS}

Animal poisoning risk by $\mathrm{HCN}$ exists when the sorghum hybrid is young and, therefore, should not be consumed when height is less than $80 \mathrm{~cm}$. In the fall culture, the best pre-grazing height of sorghum 1P400 is between 90 and $100 \mathrm{~cm}$, when leaf/stem ratio is higher and there is no risk of poisoning any longer.

\section{ACKNOWLEDGEMENTS}

This study was financed by FAPESP (grant number 2004/13427-3)

\section{REFERENCES}

DOWLING, R.M.; MCKENZIE, R.A. Poisonous plants a

Field Guide. Department of primary industries.

Queensland: Australia, 1993, 164p. 


\section{EMPRESA BRASILEIRA DE PESQUISA} AGROPECUÁRIA-EMBRAPA Centro Nacional de Pesquisa de solos (Rio de Janeiro, RJ). Sistema Brasileiro de Classificação de solos. Embrapa Produção de Informação. Brasília: Brazil. 1999, 412p.

EUCLIDES, V.P.B. et al. Consumo voluntário de forragem de três cultivares de Panicum maximum sob pastejo.

Revista Brasileira de Zootecnia, Viçosa, v.28, n.6, p.177$1185,1999$.

GILLINGHAM, J.T. et al. Relative occurrence of toxic concentrations of cyanide and nitrate in varieties of sudangrass and sorghum-sudangrass hybrids.

Agronomy Journal, Madison, v.61, n.5, p.727-730, 1969.

GORASHI, A.M. P.; DROLSOM, N.; SCHOLL, J.M. Effect of stage of growth, temperature, and $\mathrm{N}$ and $\mathrm{P}$ levels on the hydrocyanic acid potential of sorghums in the field and growth Room. Crop Science, Madison, v.20, n.1, p.45-47, 1980.

HAQUE, M.R.; BRADBURY, J.H. Total cyanide determination of plants and foods using picrate and acid hydrolysis methods. Food Chemistry, Elsevier, v.77, p.107-114, 2002.

LAMB, J.F.S. et al. Seed weight influence on seedling hydrocyanic acid potential in sorghum. Crop Science, Madison, v.31, n.4, p.1014-1016, 1991.

MELLO, R. et al. Análise produtiva e qualitativa de um híbrido de sorgo interespecífico submetido a dois cortes. Revista Brasileira de Milho e Sorgo, Sete Lagoas, v.2, n.1, p.20-33, 2003.

MONTAGNER, D.B. et al. Características agronômicas e bromatológicas de cultivares avaliados no ensaio sulrio-grandense de sorgo forrageiro. Revista Brasileira de Agrociência, Pelotas, v.11, n.4, p. 447-452, 2005.

MONTGOMERY, R.D. Cyanogenic Glycosides. In: Liener (Ed). Toxic Constituents of Plant Foodstuffs. Academic Press, New York, USA. 143-157, 1969.

MULCAHY, C.; et al. Correlation among potential selection criteria for improving the feeding value of forage sorghums. Tropical Grasslands, Colômbia, v.26, p.7-11, 1992.

NÓBREGA JUNIOR, et al. Intoxicação por Sorghum halepense (Poaceae) em bovinos no semi-árido.

Pesquisa Veterinária Brasileira, Rio de janeiro, v.26, n.4, p.201-204, 2006.

RADOSTITS, O.M. et al. Clínica veterinária: um tratado de doenças de bovinos, ovinos, caprinos, suínos e equiídeos. London, England. 2002, 1732p.

SILVA, D.S.; GOMIDE, J.A.; Fontes, C.A.A. Pressão de pastejo em pastagem de capim -elefante anão. 1 .

Estrutura e disponibilidade de pasto. Revista Brasileira de Zootecnia, Viçosa, v.23, n.2, p.249-257, 1994.

SILVA, J. D.; QUEIROZ, A.C. Análise de alimentos: métodos químicos e biológicos. 3. ed. Viçosa: UFV, p.235, 2002.

SIMILI, F.F. et al. Respostas do híbrido de sorgo-sudão às adubações nitrogenada e potássica: Características estruturais e produtivas. Ciência e Agrotecnologia, Lavras, v.34, n.1, p. 87-94, 2010.

Forage mass production and grazing loss of sorghum hybrid in response to the density of the sowing and the spacing between planting lines. Revista Brasileira de Zootecnia, Viçosa, v.40, n.7, p.1474-1479, 2011.

STATISTICALANALYSIS SYSTEM - SAS. Institute Inc. SAS/STAT User's guide. SAS Institute Inc., Cary, NC, 2003.

STOBBS, T.H. The effect of plant structure on the intake of tropical pastures. I. Variation in the bite size of grazing cattle. Australian Journal of Agricultural Research, Australia, v.24, p.809-819, 1973.

WALL, J.S.; ROSS, W. Produccion y usos del sorgo. Buenos Aires, Argentina. 1975, 399p.

WHEELER, J.L. et al. Factors affecting the hydrogen cyanide potencial of forrage sorghum. Austalian Journal of Agriculture Reseach, Australia, v.41, p.10931100, 1990. 